\title{
Herbage intake and milk production of late-lactation dairy cows offered a second-year chicory crop during summer
}

\author{
S. K. Muir, ${ }^{1}$ G. N. Ward, and J. L. Jacobs \\ Department of Economic Development, Jobs, Transport and Resources, Warrnambool, Vic 3280, Australia
}

\begin{abstract}
Chicory (Cichorum intybus L.) is a summer-active forage herb which has been proposed as an option to increase summer feed supply, increase dry matter intake, nutrient intake, and milk yield from nonirrigated dairy production systems in southern Australia. Dry matter intake, nutrient intake, milk yield, and yield of milk fat and protein of predominantly Holstein-Friesian dairy cows in late lactation consuming 3 herbage-based diets (4 replicates per treatment) were measured. The 3 grazed herbages were second-year chicory (CHIC) and perennial ryegrass (Lolium perenne L.; PRG) monocultures and a mixed sward ( $50: 50)$ of chicory and perennial ryegrass (MIX). All diets (CHIC, PRG, and MIX) were supplemented with alfalfa (Medicago sativa L.) hay (5.5 kg of DM/cow per day) and an energybased concentrate pellet (4.0 kg of DM/cow per day). There were no significant differences in milk yield $(12.0$ to $12.6 \mathrm{~kg} / \mathrm{d}$ across the treatments) or the yield of milk fat $(539$ to $585 \mathrm{~g} / \mathrm{d})$ and milk protein $(433$ to $447 \mathrm{~g} / \mathrm{d}$ ) between the 3 herbage-based diets. No differences in DMI (17.9 to $19.2 \mathrm{~kg} / \mathrm{d}$ ) or estimated metabolizable energy intake (173 to $185 \mathrm{MJ} / \mathrm{d}$ ) were noted between treatments. Estimated metabolizable energy concentrations in the forages on offer were lower in CHIC than PRG (7.6 vs. $8.2 \mathrm{MJ} / \mathrm{kg}$ of dry matter), but the concentration in consumed herbage was not different (9.1 vs. $9.2 \mathrm{MJ} / \mathrm{kg}$ of dry matter); as such, potential for increased milk yield in cows offered CHIC was limited. Increased concentration of polyunsaturated fatty acids was observed in chicory herbage compared with perennial ryegrass. This was associated with increased milk conjugated linoleic acid and milk polyunsaturated fatty acids when chicory formed part of the diet (CHIC compared to PRG and MIX). Chicory could be used as an alternative to perennial ryegrass in summer; however, the developmental stage of chicory will influence
\end{abstract}

Received November 23, 2014.

Accepted August 3, 2015.

${ }^{1}$ Corresponding author: stephanie.muir@ecodev.vic.gov.au concentrations of metabolizable energy and neutral detergent fiber and, therefore, intake and milk production responses compared with perennial ryegrass.

Key words: chicory, perennial ryegrass, milk production, nutrient selection

\section{INTRODUCTION}

The feed base in temperate southern Australian and New Zealand dairy systems is dominated by perennial ryegrass pasture (Lolium perenne L.; Chapman et al., 2008; Muir et al., 2014). However, in these regions, perennial ryegrass exhibits a highly seasonal growth pattern, with spring dominance and low summer and autumn growth, which limits the utility of this species to increase homegrown forage supply in dry land systems in southern Australia (Chapman et al., 2006, 2008). Forage herbs, such as chicory (Cichorum intybus L.), provide an option to improve feed supply and nutrient intake from the homegrown feed base over late spring, summer, and autumn (Chapman et al., 2008; Muir et al., 2014). Chicory is a summer active forage with high DM yield potential and less variable ME and $\mathrm{CP}$ concentrations in its vegetative state than perennial ryegrass (Waugh et al., 1998).

Cows grazing chicory as a supplementary forage or mixed swards based on chicory may produce more milk or more milk solids (fat + protein) compared with those consuming perennial ryegrass-based swards during summer and autumn (Waugh et al., 1998; Li and Kemp, 2005; Chapman et al., 2008). However, Minnee et al. (2012) observed that milk yield and yields of milk fat and protein were increased above those in cows grazing perennial ryegrass only when the estimated ME concentration of the perennial ryegrass was low (9.6 $\mathrm{MJ} / \mathrm{kg}$ of $\mathrm{DM})$. When the estimated ME concentration of perennial ryegrass was moderate $(10.5 \mathrm{MJ} / \mathrm{kg}$ of DM), cows supplemented with chicory had similar yields of milk and yields of milk constituents (fat + protein) to those fed perennial ryegrass pasture in both indoor and outdoor feeding experiments. This observation is consistent with the results of Muir et al. (2014), where cows consuming chicory or a mixed sward of 
chicory and perennial ryegrass had similar intakes and milk yield and concentrations of fat and protein to those grazing perennial ryegrass during spring. In that experiment, estimated herbage $\mathrm{ME}$ in the perennial ryegrass was $11.2 \pm 0.20 \mathrm{MJ} / \mathrm{kg}$ of $\mathrm{DM}$, compared with $11.3 \pm 0.14 \mathrm{MJ} / \mathrm{kg}$ of $\mathrm{DM}$ for the chicory, resulting in similar estimates of ME intake from both forage types. Milk yield averaged 27.6 and $28.0 \mathrm{~kg} /$ cow per day for the perennial ryegrass- and chicory-based diets, respectively.

In comparison to perennial ryegrass, when considered at the same ME and $\mathrm{CP}$ concentration, chicory typically has lower NDF concentrations (Waugh et al., 1998; Soder et al., 2006). It has been suggested that feeding large amounts of chicory may result in milk fat depression due to this low NDF concentration (Waugh et al., 1998; Soder et al., 2006). However, Muir et al. (2014) did not observe a depression in milk fat in cows consuming 12.5 to $14.9 \mathrm{~kg}$ of DM of chicory or a mixed sward of chicory and perennial ryegrass as the grazed forage source in the diet. Cows offered the chicory monoculture were also offered $2.2 \mathrm{~kg}$ of DM alfalfa (Medicago sativa L.) hay to maintain dietary NDF. Similarly, Minnee et al. (2012) fed diets of up to $60 \%$ chicory, without a negative effect on yield of milk fat and protein.

Altering the FA composition of milk has received considerable research attention with the aim of improving consumer health, particularly through increasing concentrations of essential FA, CLA, and increasing the concentration of unsaturated FA compared with SFA (Dewhurst et al., 2006; Elgersma et al., 2006). Feeding chicory has been associated with changes in the concentrations of beneficial FA, including CLA and PUFA (Muir et al., 2014). Concentrations of FA in milk are influenced by concentrations of FA in herbage (Dewhurst et al., 2006). During spring, chicory in a late vegetative or early reproductive phase (i.e., still leafy but with some stem elongation) contained greater concentrations of C18:2n-6, contributing to increased total PUFA in cows offered diets containing chicory (Muir et al., 2014). To our knowledge, no data exists on FA concentration or composition of chicory when fully reproductive and its subsequent effect on FA composition of milk. Marketing grass-fed milk with a more beneficial FA profile is already an option in the Netherlands (Elgersma et al., 2006), and with increasing consumer demand it may become an option for producers in other countries to add value to their production systems. Knowledge of the effect of alternative forages on the FA composition of milk will be increasingly important if producers intend to supply these markets. The hypotheses we tested were that feeding diets containing chicory during summer and in late lactation would increase DMI, nutrient selection, nutrient intake, and milk yield compared with a perennial ryegrass-based diet, and replacing perennial ryegrass with chicory in the diet would not affect milk fat concentration or milk protein yield but would increase the concentration of PUFA in milk during summer in late-lactation dairy cows.

\section{MATERIALS AND METHODS}

The experiment was conducted on a commercial dairy farm, DemoDAIRY $\left(38^{\circ} 14^{\prime} \mathrm{S}, 142^{\circ} 55^{\prime} \mathrm{E}\right)$, in southwest Victoria, Australia, during summer (January 30 to February 26, 2013). All procedures were conducted in accordance with the Australian Code of Practice for the Care and Use of Animals for Scientific Purposes (National Health and Medical Research Council, 2004). Approval to proceed was obtained from the Department of Economic Development, Jobs, Transport and Resources (DEDJTR) Agricultural Research and Extension Animal Ethics Committee.

The experiment was conducted over $24 \mathrm{~d}$, which included a 14-d adaptation period during which cows were progressively adapted to their respective herbage base by increasing the proportion of chicory in the diet (for those consuming chicory or the mixed sward). After the pre-experimental period, a 10-d measurement period occurred where DMI, nutrient concentrations in diet components, live weight, and milk production parameters were measured.

\section{Experimental Design}

The experiment was a randomized block design with 3 dietary treatments and 4 replicates or blocks. Thirtysix multiparous cows were used in the experiment, with 3 cows allocated to each replicate of a dietary treatment.

The dietary treatments were:

1. PRG: cows grazing a monoculture of perennial ryegrass supplemented with $5.5 \mathrm{~kg}$ of $\mathrm{DM} / \mathrm{d}$ alfalfa plus energy-based pellets fed at $4 \mathrm{~kg}$ of $\mathrm{DM} /$ cow per day (fed in the parlor, $50 \%$ during each milking);

2. CHIC: cows grazing a monoculture of chicory supplemented with alfalfa hay and pellets, as above; and

3. MIX: cows grazing a mixed sward of perennial ryegrass and chicory ( $\sim 50: 50 \mathrm{DM})$ supplemented with alfalfa hay and pellets, as above. 
Alfalfa hay was provided to all groups ( $50 \%$ following each milking) via 2 feed troughs $(1,000 \mathrm{~mm}$ diameter, $420 \mathrm{~mm}$ deep) located in the area allocated for grazing within each strip.

Pellets contained (as a percent of DM) wheat grain $(22 \%)$, Irwin blend (20\%, blended by-products including flour, dry distillers grain, bread crumbs, and flaked corn to $12 \mathrm{MJ} / \mathrm{kg}$ of DM ME and $15 \% \mathrm{CP}$ ), pea pollard (19.5\%), almond meal (11.4\%), mill run (10\%), grain $\operatorname{mix}(10 \%, \sim 50: 50$ wheat:barley), bentonite $(2 \%)$, lime $(2 \%)$, urea (1.3\%), molasses $(1 \%)$, salt ( $\mathrm{NaCl}, 0.5 \%)$, Diamond V XPC (0.2\%, Diamond V, Cedar Rapids, IA), mineral premix (0.1\%), and Agolin (0.01\%, Agolin SA, Biere, Switzerland). Agolin is an essential oil rumen modifier used as an alternative to ionophores. Diamond V XPC is a yeast-based product used to stimulate microbial populations. The mineral premix contained vitamins E $(7.4 \mathrm{~g} / \mathrm{kg})$ and A $(3.0 \mathrm{~g} / \mathrm{kg})$ plus cobalt $(1.5 \mathrm{~g} / \mathrm{kg})$, selenium $(0.55 \mathrm{~g} / \mathrm{kg})$, iodine $(2.0 \mathrm{~g} /$ $\mathrm{kg})$, manganese $(30.0 \mathrm{~g} / \mathrm{kg})$, zinc $(120.0 \mathrm{~g} / \mathrm{kg})$, copper $(35.0 \mathrm{~g} / \mathrm{kg})$, sulfur $(50.0 \mathrm{~g} / \mathrm{kg})$, oil $(10 \mathrm{~g} / \mathrm{kg})$, Agolin $(50.0 \mathrm{~g} / \mathrm{kg})$, and antioxidants $(1.0 \mathrm{~g} / \mathrm{kg})$. The nutritive characteristics of forages, alfalfa hay, and pellets are given in Table 1.

\section{Site and Establishment}

The soil was a brown chromosol derived from quaternary basalt (Isbell, 1996), with an A1 horizon of 25 $\mathrm{cm}$ consisting of a fine sandy clay loam and an A2 from 25 to $40 \mathrm{~cm}$ of fine sandy clay loam with many (50\%) ferruginous concretions (2-10 $\mathrm{mm}$ size). The B horizon (40-140 cm) was light to medium clay with a very firm consistency. Herbicide (Broadstrike, $40 \mathrm{~g} / \mathrm{ha}, 800 \mathrm{~g} /$ $\mathrm{kg}$ of flumetsulam; Dow Agrosciences Australia Ltd., Frenchs Forest, NSW, Australia) plus Uptake Spraying Oil $(500 \mathrm{~mL} / 100 \mathrm{~L}$ of water, $582 \mathrm{~g} / \mathrm{L}$ of paraffinic oil, $240 \mathrm{~g} / \mathrm{L}$ of alkocylated alchohol nonionic surfactants, Dow AgroSciences Australia Ltd.) was strategically applied during November and December 2011 to minimize summer weeds during establishment.

Following cultivation (in October 2011), 4 paddocks, each of 3 ha, were split equally into 3 areas running the length of the paddock. The strips within each paddock were randomly allocated and sown to either monocultures of perennial ryegrass (cv. Halo AR37; sowing rate $25 \mathrm{~kg} / \mathrm{ha}$ ) and chicory (cv. Choice; $10 \mathrm{~kg} / \mathrm{ha}$ ) or a mixed sward of perennial ryegrass $(25 \mathrm{~kg} / \mathrm{ha})$ and chicory ( $5 \mathrm{~kg} / \mathrm{ha})$.

Applications of fertilizer totaled $115 \mathrm{~kg}$ of N/ha, 49 $\mathrm{kg}$ of $\mathrm{P} / \mathrm{ha}, 75 \mathrm{~kg}$ of $\mathrm{K} / \mathrm{ha}$, and $36 \mathrm{~kg}$ of $\mathrm{S} /$ ha between establishment and the experimental period. Nitrogenbased fertilizer was applied to all forage strips both at sowing (urea, $23 \mathrm{~kg}$ of $\mathrm{N} / \mathrm{ha}$ ) and tactically during

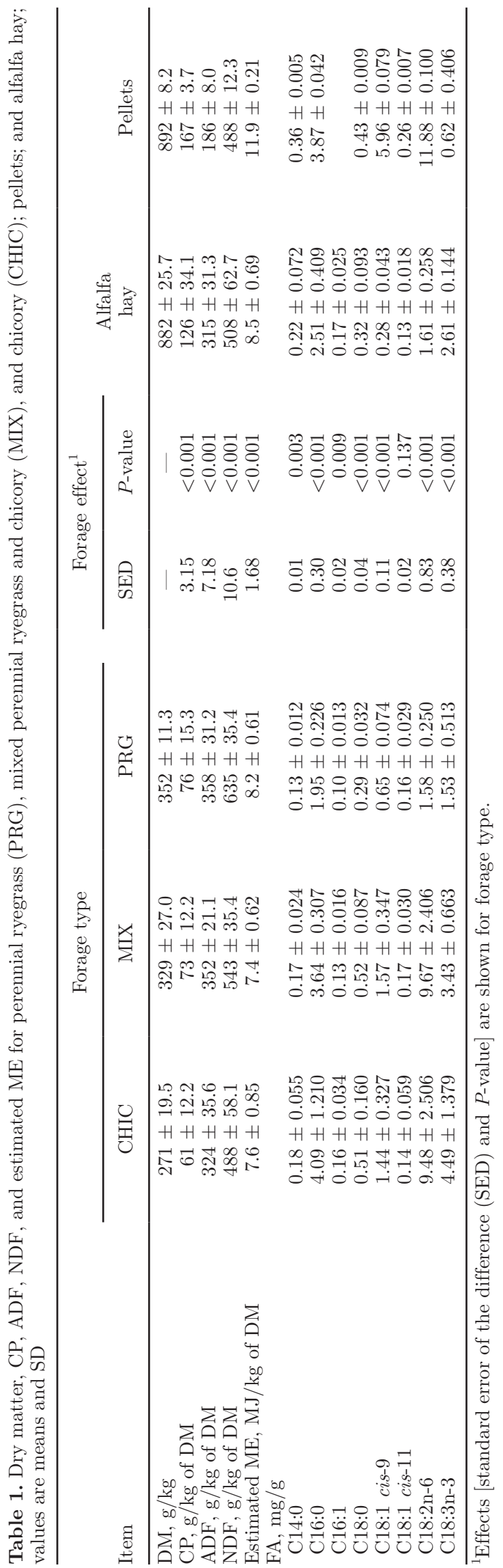

Journal of Dairy Science Vol. 98 No. 12, 2015 
Table 2. Characteristics of the predominantly Holstein-Friesian cows (mean \pm SD) allocated to diets based on chicory (CHIC), mixture of chicory and perennial ryegrass (MIX), and perennial ryegrass (PRG) at the commencement of the experiment

\begin{tabular}{lccccrc}
\hline Forage & DIM & Age, yr & $\begin{array}{c}\text { Live } \\
\text { weight, }{ }^{1} \mathrm{~kg}\end{array}$ & $\begin{array}{c}\text { Milk yield, }{ }^{2} \\
\mathrm{~kg} / \text { cow-day }\end{array}$ & $\begin{array}{c}\text { Fat, }{ }^{3} \\
\mathrm{~g} / \mathrm{kg}\end{array}$ \\
\hline CHIC & $255 \pm 27.1$ & $4.4 \pm 1.11$ & $598 \pm 63.3$ & $14.1 \pm 1.63$ & $4.5 \pm 0.34$ \\
MIX & $248 \pm 22.1$ & $4.4 \pm 1.13$ & $578 \pm 67.2$ & $15.0 \pm 2.02$ & $4.3 \pm 0.54$ & $3.5 \pm 0.32$ \\
PRG & $253 \pm 25.0$ & $5.3 \pm 1.93$ & $596 \pm 69.5$ & $15.3 \pm 2.43$ & $4.8 \pm 0.57$ & $3.4 \pm 0.21$ \\
\hline
\end{tabular}

${ }^{1}$ Live weight represents the mean of 2 consecutive days of measurement.

${ }^{2}$ Milk yield is the mean of $14 \mathrm{~d}$ of recording.

${ }^{3}$ Fat and protein are the mean of 2 spot tests (evening and morning sampling).

autumn (May, urea at $28 \mathrm{~kg}$ of $\mathrm{N} / \mathrm{ha}$ ) and spring (September, urea at $46 \mathrm{~kg}$ of $\mathrm{N} / \mathrm{ha}$ ) of 2012. Phosphorus (20 $\mathrm{kg} / \mathrm{ha})$, potassium (75 kg/ha), and sulfur $(25 \mathrm{~kg} / \mathrm{ha})$ were applied in March 2012, with diammonium phosphate $(20 \mathrm{~kg}$ of $\mathrm{P} / \mathrm{ha}, 18 \mathrm{~kg}$ of $\mathrm{N} / \mathrm{ha}$ ) applied in April 2012 and superphosphate $(8.8 \mathrm{~kg}$ of P/ha, $11 \mathrm{~kg}$ of S/ ha) applied in May 2012.

After sowing, the site was managed as was described by Muir et al. (2014). Following the previous experiment, the site was grazed $(\sim 250$ cows $)$ and mown to a uniform height $(\sim 5 \mathrm{~cm})$ during mid-December. No further grazing of the experimental area occurred until the commencement of the current experiment.

\section{Cows and Management}

Thirty-six lactating dairy cows at (mean \pm SD) 251 $( \pm 24.3)$ DIM and of predominantly Holstein-Friesian heritage were randomized based on DIM and preexperimental milk yield and milk fat production and allocated to treatment replicates using a stratified randomization procedure. Details of the cows and their milk production as used in allocation are provided in Table 2.

Cows were milked twice daily at approximately 0730 and $1600 \mathrm{~h}$. They were weighed immediately before the commencement of the experiment and daily during the experiment immediately after milking using automated walk over scales. Cows were body condition scored on a 1 to 8 scale (Earle, 1976) on d 0 and 28 of the experiment.

Each group of 3 cows was offered their herbage allocation $(32.5,38.8$, and $55.5 \mathrm{~kg}$ of $\mathrm{DM} /$ cow per day to ground level for CHIC, MIX, and PRG, respectively) as fresh breaks after each milking (60\% day, $40 \%$ night). Cows were prevented from regrazing areas that had been grazed during previous days by the use of electric fences. Forage allocation was designed to allow unrestricted intake, based on pregrazing estimates of herbage yield, anticipated potential intake or preferential selection, and forage area available. All cows had access to water ad libitum while grazing via portable troughs located in the area allocated for grazing each day.

\section{Herbage Measurements}

Pre- and postgrazing perennial ryegrass herbage mass were estimated every day for each group of 3 cows in the PRG treatment using a calibrated rising plate meter (Earle and McGowan, 1979). The rising plate meter was calibrated for pre- and post-measurements in each PRG replicate. Separate calibration equations (relating height to pasture mass in $\mathrm{kg}$ of DM/ha) were developed for pre- and postgrazing areas in each paddock. To calibrate the rising plate meter 60 (pre) and 30 (post) quadrants of $0.1 \mathrm{~m}^{2}$ were cut to ground level over the duration of the experiment. Samples were washed in cold water to remove soil and foreign material before being dried for at least $48 \mathrm{~h}$ at $100^{\circ} \mathrm{C}$ to estimate DM yield (Jacobs and Ward, 2011). Fifty plate meter readings were taken in each grazed and offered area to estimate pre- and postgrazing herbage mass each day during the measurement period. Average height was related to pasture mass using the previously described calibration equation.

Pregrazing forage mass (chicory and mixed swards) were estimated daily by cutting 6 quadrants $\left(0.25 \mathrm{~m}^{2}\right)$ to ground level along a diagonal transect covering the daily allocation area for each forage type within each replicate. Samples were weighed, thoroughly mixed, and subsampled before being dried for $48 \mathrm{~h}$ at $100^{\circ} \mathrm{C}$ to estimate pregrazing forage mass ( $\mathrm{kg}$ of $\mathrm{DM} / \mathrm{ha})$. An additional subsample of the mixed sward was hand sorted into herbage components (chicory, perennial ryegrass, other). Postgrazing forage mass (chicory and mixed swards) was estimated as described above by cutting 6 quadrats along a diagonal transect covering the previous days grazed area. Samples were washed in cold water to remove soil and foreign material before being dried at $100^{\circ} \mathrm{C}$ for at least $48 \mathrm{~h}$ for measurement of postgrazing DM yield. Average forage DMI for each replicate was estimated for each day as forage DMI = 
[pregrazing mass ( $\mathrm{kg}$ of DM/ha) - postgrazing mass ( $\mathrm{kg}$ of DM/ha)] $\times$ area/number of cows.

\section{Supplement Intake}

Pellets (concentrate) were offered in the parlor during morning and afternoon milking in 2 equal meals. We observed no refusals of concentrate.

\section{Nutritive Characteristics}

Throughout the measurement period, samples of supplementary feeds, alfalfa residues, and pre- and postgrazing herbages (for each replicate in the 3 treatments) were collected daily. All pre- and postgrazing herbage samples were collected by manually cutting herbage to ground level at a minimum of 10 points along a transect of the respective grazing areas. Each sample (herbage, supplementary feeds, alfalfa hay, and residues) was stored on ice and washed to remove contaminants before being dried at $60^{\circ} \mathrm{C}$ for $72 \mathrm{~h}$ (Jacobs and Ward, 2011) and ground (Foss Cyclotec 1093 Sample Mill, Foss, Hillerød, Denmark) through a 1-mm screen.

Herbage and supplementary feed samples were analyzed at DEDJTR Horsham, Victoria, Australia, by near-infrared spectroscopy (NIRS) spectra. The NIRS were collected on all samples using an XDS Rapid Content Analyzer (Foss) in conjunction with WinISI II v.1.04 software (Infrasoft International LLC, State College, PA). Near-infrared spectroscopy calibrations for $\mathrm{CP}, \mathrm{NDF}, \mathrm{ADF}$, and in vitro $\mathrm{DM}$ digestibility (IVDMD) had previously been derived from large sample populations collected over multiple seasons and using a range of herbages from multiple locations using the procedures of Shenk and Westerhaus (1991). This database comprised close to 800 samples, including PRG and CHIC, other forages, concentrates, and grains. Standard errors of prediction for CP, NDF, $\mathrm{ADF}$, and IVDMD in herbages were 1.0, 2.5, 1.7, and $2.0 \%$ DM, respectively. A comparison between NIRS and wet chemistry was undertaken for $10 \%$ of samples (randomly selected), with resultant correlations $\left(\mathrm{R}^{2}\right)$ of $0.99,0.96,0.97$, and 0.95 for $\mathrm{CP}, \mathrm{ADF}, \mathrm{NDF}$, and IVDMD, respectively (J. Panozzo, DEDJTR Horsham, Victoria, Australia, personal communication). Any spectral outliers from the calibrations had analysis by NIRS repeated and were further analyzed by wet chemistry techniques. Spectral outliers tended to be the result of improper sample preparation for the NIRS system, and after repeated analysis results were within the acceptable range.

Reference methods used for NIRS calibrations were as follows: CP using the Kjeldahl method, NDF by the method of Van Soest and Wine (1967), including amylase and sodium sulfite on a DM basis, and IVDMD using a pepsin-cellulase technique (Clarke et al., 1982), with analytical values adjusted using a linear regression based on similar samples of known IVDMD. The ADF concentration of the samples were determined using Method 1.9A(a) [ANKOM method] as described in Australian Fodder Industry Association Ltd. (2011)

Digestible organic matter in dry matter (DOMD) was calculated using the formula (CSIRO, 2007):

$$
\mathrm{DOMD} \%=7.32+0.84 \mathrm{DM} \text { digestibility }(\%) \text {. }
$$

Estimated ME (MJ $/ \mathrm{kg}$ of $\mathrm{DM})$ values were calculated from predicted DOMD values using the following formulas (Australian Fodder Industry Association Ltd., 2011) for forage as well as grains and concentrates, respectively:

$$
\begin{gathered}
\mathrm{ME}=0.203 \times \operatorname{DOMD}(\%)-3.001, \text { and } \\
\mathrm{ME}=0.858+0.138 \times \mathrm{DOMD}(\%) \\
+0.272 \times \text { fat }(\%) .
\end{gathered}
$$

Additional herbage samples (cut to ground level) were collected on d 6 to 8 of the measurement period. Samples stored on ice and washed before being freeze-dried, ground (Foss Cyclotec 1093 Sample Mill, Foss) through a 1-mm screen, and analyzed for FA composition following toluene extraction, using the method of Sukhija and Palmquist (1988).

\section{Milk Yield and Composition}

Milk yield of every cow was measured at every milking during both periods (adaptation and measurement) using a DeLaval Alpro milking metering system (DeLaval International, Tumba, Sweden). A proportionate sample of the daily milk (both evening + morning) was taken on $\mathrm{d} 5$ during the measurement period using inline milk meters (DeLaval International). Milk samples were combined by day (evening + morning) based on total milk volume collected for individual cows and subsampled $(\sim 30 \mathrm{~mL})$ for analysis of fat, protein, and lactose. Milk samples were tested for concentrations of fat, protein, and lactose using an infrared milk analyzer (Bentley 2000, Bentley Instruments, Chaska, MN).

Additional composite samples of milk were taken on 3 consecutive days (6 to 8 ) during the measurement period. Milk from individual cows was proportionately pooled based on yield at evening and morning milkings then by total milk yield within a replicate group of 3 cows. Bulked samples were analyzed for FA according 
to the methods of Feng et al. (2004) and Luna et al. (2005). Protein fractions were also analyzed using the approach of Bordin et al. (2001). Analyses for both FA concentrations (forage and milk) and protein fractions (milk) were undertaken by Ag Research, NZ (Ruakura Research Centre, Hamilton, New Zealand).

\section{Calculations and Statistical Analysis}

For DMI, nutrient selection, and nutrient intake, it was assumed that all 3 cows in each replicate consumed the same amount of forage and alfalfa hay. Differences in nutritive characteristics between pre- and postgrazing samples were used to estimate nutrient intakes from grazed material.

The concentration of nutrient $\left(\mathrm{N}_{\text {sel }}\right)$ in herbage selected by cows was calculated as (Jacobs et al., 1999):

$\mathrm{N}_{\text {sel }}=\left[\left(\mathrm{M}_{\text {pre }} \times \mathrm{N}_{\text {pre }}\right)-\left(\mathrm{M}_{\text {post }} \times \mathrm{N}_{\text {post }}\right)\right] /\left(\mathrm{M}_{\text {pre }}-\mathrm{M}_{\text {post }}\right)$,

where $M_{\text {pre }}$ and $M_{\text {post }}$ are the mass of the pre- and postgrazed herbage and $\mathrm{N}_{\text {pre }}$ and $\mathrm{N}_{\text {post }}$ are the concentration of the nutrient in the pre- and postgrazed herbage, respectively.

The selection differential was calculated as: $\mathrm{N}_{\text {sel }} / \mathrm{N}_{\text {pre }}$. Herbage utilization was calculated as $\left[\left(\mathrm{M}_{\text {pre }}-\mathrm{M}_{\text {post }}\right) /\right.$ $\left.\mathrm{M}_{\text {pre }}\right] \times 100$. Energy-corrected milk standardized to $4.0 \%$ fat and $3.3 \%$ protein was calculated using the following formula (Tyrrell and Reid, 1965):

$$
\begin{gathered}
\text { ECM }(\mathrm{kg} / \text { cow per day })=\text { milk yield } \mathrm{kg} \\
\times[376 \times \text { fat }(\%)+209 \times \text { protein }(\%)+948] / 3,138
\end{gathered}
$$

Statistical analyses were conducted on measurement period (10 d) means for each group of 3 cows. Energycorrected milk yield, milk yield, milk fat concentration and yield, and protein concentration and yield were derived by averaging over the treatment period within cows before averaging over cows within groups. All factors were analyzed by ANOVA, with a single treatment (diet type) blocked by paddock.

\section{RESULTS}

Long-term average rainfall for December, January, and February was 44.4, 32.9 and $34.3 \mathrm{~mm}$, respectively. Mean monthly minimum temperatures were 11.6, 12.8, and $13.3^{\circ} \mathrm{C}$ for December, January, and February, respectively, with corresponding mean maximum temperatures of $20.7,22.2$, and $22.3^{\circ} \mathrm{C}$. Between December 2012 and March 2013, total rainfall was $63 \mathrm{~mm}$, falling primarily during December. During the experimental period (January 30 to February 26), mean minimum temperature was $12.8^{\circ} \mathrm{C}$ and mean maximum temperature was $27.3^{\circ} \mathrm{C}$.

The chemical composition of forages and supplementary feed ingredients are presented in Table 1. Estimated ME $(\mathrm{MJ} / \mathrm{kg}$ of $\mathrm{DM})$ was lower $(P<0.001)$ in CHIC (7.6) and MIX (7.4) than PRG (8.2). Crude protein concentration of the forages ranged from 61 to $76 \mathrm{~g} / \mathrm{kg}$ of DM and was lowest $(P<0.001)$ in CHIC. Neutral detergent fiber concentration was lowest $(P<0.001)$ in CHIC (488 g/ $\mathrm{kg}$ of DM) and highest in PRG (635 g/ $\mathrm{kg}$ of DM). Apart from ME concentration, the nutritive characteristics of the MIX sward were midway between the CHIC and PRG swards. Herbage from CHIC had higher $(P<0.01)$ concentrations of C14:0, C16:0, C16:1, C18:0, C18:1 cis-9, C18:2n-6, and C18:3n-3 FA compared with the PRG.

Herbage allowance (Table 3, to ground level) was significantly different $(P<0.05)$ among herbage types, with allowance highest (55.5 kg of DM/cow per day) for the PRG treatments, and lowest for the CHIC treatment (32.5 kg of DM/cow per day). No significant differences were observed between treatments in intake of herbage, alfalfa hay, or total DM $(P>0.05)$. Pregrazing herbage mass (Table 3$)$ differed $(P<0.001)$ between herbage types, averaging $2,882,1,557$, and $2,024 \mathrm{~kg}$ of $\mathrm{DM} / \mathrm{ha}$ to ground level in the PRG, CHIC, and MIX treatments, respectively. Herbage utilization (Table 3 ) was low and averaged 31,26 , and $15 \%$ in the CHIC, MIX, and PRG herbages, respectively. The monocultures were $>90 \%$ of the sown herbage (visual estimate), whereas the mixed sward averaged $75 \%$ chicory (hand-sorted subsample of forage).

Dietary treatment did not affect milk yield, ECM, the concentrations of fat and protein in milk (Table 3 ), or total production of fat and protein (data not presented). Milk produced per kilogram of DMI was not affected by dietary treatment, with $0.70 \mathrm{~kg}$ of milk/ $\mathrm{kg}$ of DMI for cows offered PRG, compared with 0.66 and $0.63 \mathrm{~kg}$ of milk $/ \mathrm{kg}$ of DMI for cows offered CHIC and MIX, respectively.

No significant differences were noted in live weight and BCS of cows on different treatments at the end of the measurement period. Change in BCS over the duration of the experiment was not significantly different between treatments and was small (0-0.15 units; Table 3).

Concentrations of both de novo and herbage-sourced FA in milk differed between diets (Table 4). Concentrations of de novo FA were increased $(P<0.05)$ in PRG compared with CHIC and MIX, short-chain FA tended to increase with PRG, whereas C18:0 and some of the longer-chain FA increased in MIX and CHIC (Table 4). Concentrations of PUFA were increased $(P<0.001)$ in CHIC $(2.58 \mathrm{mg} / \mathrm{g})$ and MIX (2.40 mg/g) compared 
with PRG $(1.97 \mathrm{mg} / \mathrm{g})$. Concentration of linolenic acid $(\mathrm{C} 18: 2 \mathrm{n}-6)$ and linoleic acid $(\mathrm{C} 18: 3 \mathrm{n}-3)$ increased $(P$ $<0.01)$ in MIX and CHIC compared with PRG. Concentration of CLA in milk approached significance $(P$ $=0.051)$, tending to be higher in the MIX $(0.39 \mathrm{mg} / \mathrm{g})$ and CHIC $(0.40 \mathrm{mg} / \mathrm{g})$ than in PRG $(0.33 \mathrm{mg} / \mathrm{g})$. Diet did not affect the concentration of casein and whey protein fractions in milk (Table 5).

\section{DISCUSSION}

The hypothesis that DMI would be higher in cows offered CHIC or MIX diets compared with PRG diets was rejected, as we found no difference in DMI. Muir et al. (2014) reported that during spring, cows in mid lactation consumed approximately $12 \mathrm{~kg}$ of $\mathrm{DM} / \mathrm{cow}$ per day of a chicory monoculture or $14 \mathrm{~kg}$ of $\mathrm{DM} /$ cow per day of a mixed sward (chicory and perennial ryegrass), whereas Chapman et al. (2008) reported that cows consumed $19 \mathrm{~kg}$ of DM/day while grazing a sward in summer comprising $80 \%$ chicory, albeit newly sown and therefore still vegetative. However, such intake was not realized in the current experiment, due to (1) the need to provide supplementary feed (in the form of alfalfa hay and concentrate pellets) due to low forage availability [decile 1 (lowest) rainfall for the 3 mo before start of the experiment] or (2) the nutritive characteristics of the chicory itself. These factors require consideration when feeding chicory in a reproductive state.

The chicory-based sward measured by Chapman et al. (2008) was in its first year of growth and was unlikely to show the significant reproductive stem development in chicory observed in our experiment. Intake of a second-year chicory sward is restricted by the presence of stem material, which is less palatable, and has lower ME and higher NDF concentrations than a first-year chicory sward (Soder et al., 2006). In its reproductive state, total intake of chicory can be limited by disinclination to graze stem material (Soder et al., 2006). The study of Muir et al. (2014) also used second-year chicory but was conducted in spring, when chicory was transitioning between vegetative and the initial stages of reproductive development; as such, ME concentrations were still high $(11.3 \mathrm{MJ} / \mathrm{kg}$ of $\mathrm{DM})$ and NDF concentrations were low $(285 \mathrm{~g} / \mathrm{kg}$ of DM) and would not have restricted DMI.

Differences in nutrients between the leaf and stem components of a plant are a major determinant of selection differentials and may influence total intake or utilization of forage (Dalley et al., 1999). Typically,

Table 3. Effects of diets based on grazed chicory (CHIC), a mixture of chicory and perennial ryegrass (MIX), and perennial ryegrass (PRG) on nutrient intake and milk production of Holstein-Friesian cows in late lactation

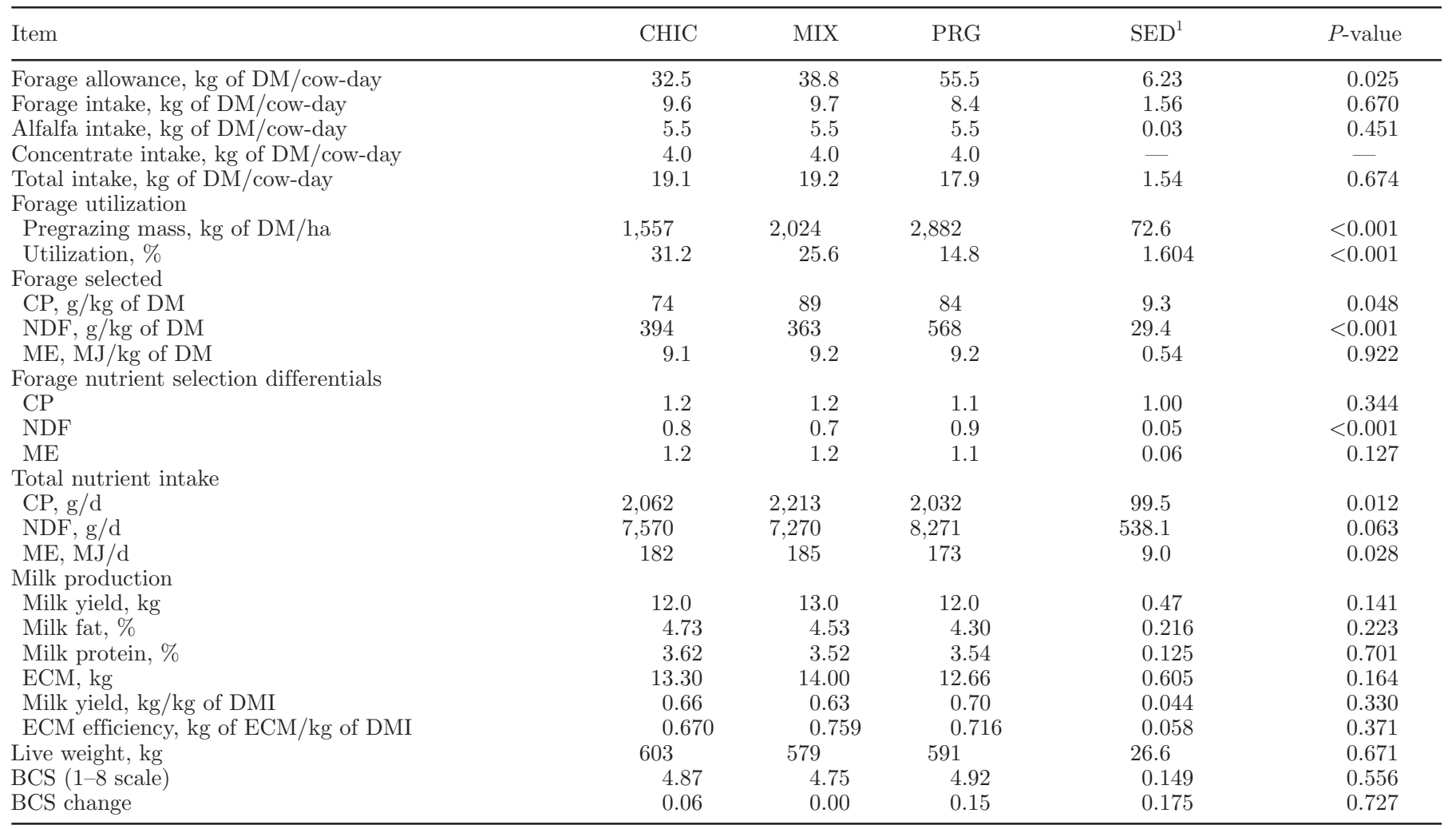

${ }^{1}$ Standard error of the difference. 
Table 4. Effects of diets based on grazed chicory (CHIC), a mixture of chicory and perennial ryegrass (MIX), and perennial ryegrass (PRG) on milk FA composition (g/100 g of FA)

\begin{tabular}{|c|c|c|c|c|c|}
\hline Item & $\mathrm{CHIC}$ & MIX & PRG & $\mathrm{SED}^{1}$ & $P$-value \\
\hline $\mathrm{C} 4: 0$ & 4.17 & 4.10 & 3.85 & 0.103 & 0.046 \\
\hline C6:0 & 2.17 & 2.18 & 2.21 & 0.053 & 0.740 \\
\hline C8:0 & 1.06 & 1.08 & 1.13 & 0.041 & 0.296 \\
\hline C10:0 & 2.20 & 2.29 & 2.59 & 0.111 & 0.029 \\
\hline C10:1 & 0.27 & 0.27 & 0.29 & 0.016 & 0.559 \\
\hline C12:0 & 2.54 & 2.63 & 3.04 & 0.143 & 0.028 \\
\hline iso C14 & 0.14 & 0.15 & 0.19 & 0.007 & 0.001 \\
\hline C14:0 & 11.22 & 11.60 & 12.75 & 0.276 & 0.004 \\
\hline iso $\mathrm{C} 15$ & 0.29 & 0.31 & 0.40 & 0.018 & 0.002 \\
\hline $\mathrm{C} 14: 1 /$ anteiso $\mathrm{C} 15$ & 1.54 & 1.51 & 1.72 & 0.097 & 0.148 \\
\hline $\mathrm{C} 15: 0$ & 1.23 & 1.22 & 1.26 & 0.049 & 0.711 \\
\hline C16:0 & 37.74 & 37.15 & 39.50 & 1.324 & 0.261 \\
\hline iso $\mathrm{C} 17$ & 0.40 & 0.39 & 0.42 & 0.018 & 0.228 \\
\hline C16:1 & 1.58 & 1.44 & 1.47 & 0.123 & 0.519 \\
\hline anteiso $\mathrm{C} 17$ & 0.45 & 0.44 & 0.50 & 0.021 & 0.062 \\
\hline $\mathrm{C} 17: 0$ & 0.70 & 0.70 & 0.78 & 0.021 & 0.015 \\
\hline C17:1 C9 & 0.32 & 0.31 & 0.31 & 0.027 & 0.852 \\
\hline C18:0 & 8.21 & 8.58 & 6.98 & 0.278 & 0.003 \\
\hline C18:1 trans-9 & 0.13 & 0.13 & 0.11 & 0.097 & 0.155 \\
\hline C18:1 trans-10 & 0.21 & 0.22 & 0.18 & 0.091 & 0.018 \\
\hline C18:1 trans-11 & 0.66 & 0.67 & 0.58 & 0.031 & 0.058 \\
\hline $\mathrm{C} 18: 1$ cis-9 & 17.15 & 17.33 & 14.89 & 1.003 & 0.092 \\
\hline C18:1 cis-11 & 0.29 & 0.27 & 0.28 & 0.021 & 0.605 \\
\hline C18:2n-6 & 1.40 & 1.32 & 1.14 & 0.027 & $<0.001$ \\
\hline C20:0 & 0.13 & 0.15 & 0.15 & 0.075 & 0.117 \\
\hline C18:3n-3 & 0.67 & 0.60 & 0.39 & 0.042 & 0.001 \\
\hline $\mathrm{CLA}^{2}$ & 0.40 & 0.39 & 0.33 & 0.022 & 0.051 \\
\hline $\mathrm{C} 22: 5$ & 0.11 & 0.10 & 0.11 & 0.005 & 0.371 \\
\hline Unknown $^{3}$ & 2.62 & 2.47 & 2.45 & 0.060 & 0.059 \\
\hline Total saturated & 60.34 & 60.29 & 61.79 & 1.246 & 0.441 \\
\hline Total monounsaturated & 24.76 & 24.62 & 22.28 & 1.151 & 0.129 \\
\hline Total polyunsaturated & 2.58 & 2.40 & 1.97 & 0.080 & $<0.001$ \\
\hline De novo & 45.70 & 45.92 & 49.17 & 0.916 & 0.016 \\
\hline
\end{tabular}

${ }^{1}$ Standard error of the difference.

${ }^{2}$ CLA reported is cis-9,trans-11 CLA. trans-10, cis-12 CLA is present but is below the detection threshold.

${ }^{3}$ Unknown includes isomers of $\mathrm{C} 18: 1, \mathrm{C} 18: 2, \mathrm{C} 14: 1$, and $\mathrm{C} 16: 1$ present below the detection threshold.

selection differentials are lower for NDF and higher for $\mathrm{CP}$ and $\mathrm{ME}$, indicating animals preferentially select leaf over stem material at high herbage allowances. The flowering observed (anecdotal) in the CHIC and MIX swards during our experiment typically limits utilization and nutrient intake of chicory due to avoidance of fibrous stem material (Soder et al., 2006). Selection differential for NDF was lower $(P<0.01)$ for the mixed and chicory swards, supporting avoidance of grazing more fibrous stem material. In the current experiment, utilization of all herbage types was low, but lower in the PRG $(15 \%)$ than MIX (26\%) or CHIC (31\%) herbage. Given the prevailing climatic conditions leading up to and during the experiment (decile 1 rainfall),

Table 5. Milk protein composition $(\mathrm{mg} / \mathrm{g})$ in cows fed diets based on grazed chicory (CHIC), a mixture of chicory and perennial ryegrass (MIX), and perennial ryegrass (PRG)

\begin{tabular}{|c|c|c|c|c|c|}
\hline Item & $\mathrm{CHIC}$ & MIX & PRG & $\mathrm{SED}^{1}$ & $P$-value \\
\hline$\kappa-\mathrm{CN}$ & 4.95 & 4.76 & 5.19 & 0.369 & 0.543 \\
\hline$\alpha_{\mathrm{S} 2}-\mathrm{CN}$ & 9.16 & 9.43 & 9.90 & 0.372 & 0.215 \\
\hline$\alpha_{\mathrm{S} 1}-\mathrm{CN}$ & 11.54 & 11.20 & 11.32 & 0.635 & 0.864 \\
\hline$\beta-\mathrm{CN}$ & 11.60 & 10.44 & 11.61 & 0.556 & 0.129 \\
\hline Total CN & 37.26 & 35.83 & 38.01 & 1.185 & 0.250 \\
\hline$\alpha-\mathrm{LG}$ & 1.25 & 1.19 & 1.34 & 0.08 & 0.254 \\
\hline$\beta-\mathrm{LG} B$ & 1.81 & 1.60 & 1.81 & 0.297 & 0.732 \\
\hline$\beta-L G A$ & 3.32 & 3.91 & 2.93 & 0.763 & 0.479 \\
\hline Total whey & 6.39 & 6.70 & 6.08 & 0.467 & 0.458 \\
\hline
\end{tabular}

${ }^{1}$ Standard error of the difference. 
low forage accumulation rates, and the relatively poor nutritive characteristics of all plant species offered, it is not surprising that utilization was low despite adequate allowance rates. Furthermore, approximately $45 \%$ of the diet was offered as supplements, which would affect utilization rates. Such allowances were offered so as to ensure animals were able to consume additional forage if motivated to do so, and are typical of farm practice at this time of year. The higher allowance of PRG compared with the other treatments was due to the high proportion of DM that was considered to be below grazing height; therefore, allowance was increased to ensure adequate DMI animals in this treatment.

The ME concentration of the perennial ryegrass was low when compared with previous observations in southern Victoria during summer: 7.0 to $10.8 \mathrm{MJ} / \mathrm{kg}$ of DM (Jacobs et al., 1999), $10 \mathrm{MJ} / \mathrm{kg}$ of DM (Chapman et al., 2008), and 9.5 to $11 \mathrm{MJ} / \mathrm{kg}$ of DM (Tharmaraj et al., 2008). However, unexpectedly, the estimated ME concentration in the perennial ryegrass was higher than chicory $(P<0.001)$. In the herbage selected, ME concentrations were similar $(P>0.05)$, at $9.1,9.2$, and $9.2 \mathrm{MJ} / \mathrm{kg}$ of DM for CHIC, MIX, and PRG, respectively. In perennial ryegrass pasture, ME concentration declines between spring and summer as the proportion of dead herbage increases (Doyle et al., 2000). We suggest that the ME estimates in our experiment were related to low rainfall $(\sim 61 \%$ average, decile 1$)$ over late summer that effectively resulted in the perennial ryegrass being preserved as a standing hay and avoiding a decline in ME concentration. Loss of nutrients in standing hay is typically attributed primarily to rainfall and humidity, leading to leaching of soluble substrates and molding (McCown and Wall, 1981, 1989). The low rainfall observed during this experiment could potentially have limited molding and therefore slowed the loss of nutrients in the perennial ryegrass, producing standing hay higher in ME than the summer active chicory.

The ME concentration of the chicory was not maintained over the growing season as anticipated. A chicory sward in its first year is expected to remain vegetative and will subsequently maintain consistent concentrations of $\mathrm{ME}$ and $\mathrm{CP}$ as the growing season progresses (Labreveux et al., 2006). Both ME and CP concentrations decline and NDF concentration increases, as the chicory sward becomes reproductive, typically from its second year of growth onwards (Labreveux et al., 2006). This change is attributed to the presence of more stem and less leaf material (Labreveux et al., 2006). A second-year chicory sward that contained reproductive stem material was used in the current study. This sward had lower concentrations of ME and CP in its second year compared with its vegetative state
(Muir et al., 2014). Differences in ME concentration of chicory and perennial ryegrass may also be due to the different growth habits of chicory and perennial ryegrass. Being shallow rooted, we contend that the perennial ryegrass stopped growing once easily accessible soil moisture was depleted, although soil moisture concentration was not measured. The chicory, with a taproot structure (Skinner et al., 2004), was more likely to be able to exploit deeper reserves of soil moisture and continue growing later into spring; however, when soil moisture was depleted during summer, the chicory not only stopped vegetative growth but entered its reproductive phase with a subsequent decline in nutritive value. The higher-than-expected ME in the perennial ryegrass and low ME in the second-year chicory sward resulted in similar ME concentrations for the 2 forages and forage mix and significant differences in total ME intake and, we suggest, limited the potential to observe an increase in milk production associated with feeding chicory-based forage, as hypothesized.

The hypothesis that milk yield would be increased in cows offered CHIC or MIX was rejected. Milk yield was not different between cows offered all herbage types, despite significant differences in nutrient intakes. Minnee et al. (2012) reported that when ME concentration of perennial ryegrass and chicory were similar, milk yield was not different in cows offered chicory compared with those offered perennial ryegrass. Similarly, Muir et al. (2014) observed no difference in milk yield between chicory, a mixed sward, and perennial ryegrass, all of which had similar ME concentrations.

The hypothesis that replacing perennial ryegrass in the diet with chicory would not affect milk fat and protein concentration was supported. Typically, the NDF concentration of chicory is lower than perennial ryegrass (when considered at similar levels of ME and $\mathrm{CP}$ ) and milk fat concentration is expected to decline in cows offered chicory due to lower NDF concentration in forage (Waugh et al., 1998; Soder et al., 2006). However, evidence exists that cows can consume chicory as the sole dietary forage without negatively affecting milk yield. Muir et al. (2014) fed chicory at up to $12 \mathrm{~kg}$ of $\mathrm{DM} / \mathrm{cow}$ per day with $2 \mathrm{~kg}$ of $\mathrm{DM} /$ cow per day of alfalfa hay, and cows selected a diet with an NDF concentration closer to $25 \%$. This NDF concentration, despite being lower than recommended (Standing Committee on Agriculture, 1990), did not negatively affect milk fat concentration. For lactating dairy cows, an NDF concentration between 30 and $40 \%$ is recommended (Standing Committee on Agriculture, 1990; Wales et al., 2006). In the current experiment, intake of NDF, combined with supplementary alfalfa hay (in all diets), maintained NDF intake at a sufficient level to avoid milk fat depression. From our study, NDF 
concentration of each herbage type was greater than $40 \%$, with NDF in selected herbage ranging from 33 to $56 \%$, well within the recommended range. Our results demonstrate that a reproductive chicory sward can be fed during summer as the sole grazed forage, in association with alfalfa hay, without negatively affecting milk fat concentration.

Concentration of beneficial milk FA, such as PUFA and CLA, has been shown to increase when cows are fed chicory compared with perennial ryegrass (Muir et al., 2014) and a mixed sward containing chicory compared with grass and clover mixes (Soder et al., 2006). Although overall milk fat concentration was not different, concentrations of beneficial milk FA were influenced by herbage type. Concentration of CLA in milk from cows consuming chicory and the mixed sward was higher $(P$ $=0.051)$ than from cows fed perennial ryegrass. The current experiment is in contrast with the results of Muir et al. (2014), who observed a lower concentration of CLA in cows offered a chicory-based diet. However, the forage component of the chicory-based diet offered by Muir et al. (2014) also contained alfalfa hay, whereas the perennial ryegrass diet contained no hay, which is likely to have affected milk CLA concentration. Conserved forage is typically lower in CLA than fresh herbage (Dewhurst et al. 2006); therefore, at the same level of intake, the chicory and alfalfa diet could be expected to have a lower concentration of CLA compared with the other herbage types. The concentration of PUFA was higher $(P<0.001)$ in milk from cows grazing MIX or CHIC. This increase in PUFA was associated with an increase $(P<0.01)$ in both linoleic and linolenic acids. Both linoleic and linolenic acids were present in higher concentrations in chicory than perennial ryegrass (Muir et al., 2014). These results provide further evidence that feeding chicory can increase concentrations of beneficial milk FA compared with a perennial ryegrass-based diet.

\section{CONCLUSIONS}

The second-year chicory sward had lower ME concentration than the perennial ryegrass; however, ME selected from all forage types was similar, contributing to similar milk yields in all herbage types. The lowerthan-expected ME concentration in the chicory herbage was likely to be related to low summer rainfall as well as the sward being in its second year of summer growth and in a reproductive rather than vegetative state. Therefore, although a reproductive chicory sward, in association with hay and concentrate, will maintain milk production over summer in late lactation, compared with perennial ryegrass there may be limited potential for increases in milk yield in an environment of low summer rainfall.

\section{ACKNOWLEDGMENTS}

The authors are grateful to K. Renstch, S. Burch, J. Hollier, M. Brophy (Department of Economic Development, Jobs, Transport and Resources, Warrnambool) and DemoDAIRY (Terang, Victoria) farm staff. Analysis of fatty acids in feed and milk and milk protein fractions was completed by Ag Research (Ruakura Research Centre, Hamilton, New Zealand). This research was funded by the Department of Economic Development, Jobs, Transport and Resources and Dairy Australia (Melbourne, Australia).

\section{REFERENCES}

Australian Fodder Industry Association Ltd. 2011. AFIA - Laboratory Methods Manual. A Reference Manual for the Analysis of Fodder. Vol. 7. September 2011. Australian Fodder Industry Association Ltd., Melbourne, Australia.

Bordin, G., F. Cordeiro Raposo, B. de la Calle, and A. R. Rodriguez. 2001. Identification and quantification of major bovine milk proteins by liquid chromatography. J. Chromatogr. A 928:63-76.

Chapman, D. F., J. L. Jacobs, G. N. Ward, G. B. O'Brien, S. N. Kenny, D. Beca, and F. R. McKenzie. 2006. Forage supply systems for dryland dairy farms in southern Australia. Pages 255-260 in Proc. NZ Grassl. Assoc. vol. 68. New Zealand Grassland Assoc. Dunedin, New Zealand.

Chapman, D. F., J. Tharmaraj, and Z. N. Nie. 2008. Milk-production potential of different sward types in a temperate southern Australian environment. Grass Forage Sci. 63:221-233.

Clarke, T., P. C. Flinn, and A. A. McGowan. 1982. Low cost pepsincellulase assays for prediction of digestibility of herbage. Grass Forage Sci. 37:147-150.

CSIRO. 2007. Nutrient Requirements of Domesticated Ruminants. M. Freer, H. Dove, and J. V. Nolan, ed. CSIRO Publishing, Melbourne, Australia.

Dalley, D. E., J. R. Roche, C. Grainger, and P. J. Moate. 1999. Dry matter intake, nutrient selection and milk production of dairy cows grazing rainfed perennial pastures at different herbage allowances in spring. Aust. J. Exp. Agric. 39:923-931.

Dewhurst, R. J., K. J. Shingfield, M. R. F. Lee, and N. D. Scollan. 2006. Increasing the concentrations of beneficial polyunsaturated fatty acids in milk produced by dairy cows in high-forage systems. Anim. Feed Sci. Technol. 131:168-206.

Doyle, P. T., C. R. Stockdale, A. R. Lawson, and D. C. Cohen. 2000. Pastures for Dairy Production in Victoria, 2nd ed. Department of Natural Resources and Environment, Victoria, Australia.

Earle, D., and A. McGowan. 1979. Evaluation and calibration of an automated rising plate meter for estimating dry matter yield of pasture. Anim. Prod. Sci. 19:337-343.

Earle, D. F. 1976. A guide to scoring dairy cow condition. J. Agric (Victoria) 74:228-231.

Elgersma, A., S. Tamminga, and G. Ellen. 2006. Modifying milk composition through forage. Anim. Feed Sci. Technol. 131:207-225.

Feng, S., A. L. Lock, and P. C. Garnsworthy. 2004. Technical note: A rapid lipid separation method for determining fatty acid composition of milk. J. Dairy Sci. 87:3785-3788.

Isbell, R. 1996. The Australian Soil Classification. CSIRO Publishing, Melbourne, Australia.

Jacobs, J. L., F. R. McKenzie, and G. N. Ward. 1999. Changes in the botanical composition and nutritive characteristics of pasture, and nutrient selection by dairy cows grazing rainfed pastures in western Victoria. Aust. J. Exp. Agric. 39:419-428.

Jacobs, J. L., and G. N. Ward. 2011. Effect of nitrogen application on dry matter yield, nutritive characteristics and mineral conten of summer-active forage crops in southern Australia. Anim. Prod. Sci. 51:77-86. 
Labreveux, M., M. A. Sanderson, and M. H. Hall. 2006. Forage chicory and plantain: nutritive value of herbage at variable grazing frequencies and intensities. Agron. J. 98:231-237.

Li, G., and P. D. Kemp. 2005. Forage chicory (Cichorium intybus L.): A review of its agronomy and animal production. Adv. Agron. 88:187-222.

Luna, P., M. Juarez, and M. A. de la Fuente. 2005. Validation of a rapid milk fat separation method to determine the fatty acid profile by gas chromatography. J. Dairy Sci. 88:3377-3381.

McCown, R. L., and B. H. Wall. 1981. The influence of weather on the quality of tropical legume pasture during the dry season in Northern Australia. II. Moulding of standing hay in relation to rain and dew. Aust. J. Agric. Res. 32:589-598.

McCown, R. L., and B. H. Wall. 1989. The influence of weather on the quality of tropical legume pasture during the dry season in Northern Australia. III. Effects of digestibility and chemical composition. Aust. J. Agric. Res. 40:573-578.

Minnee, E. M. K., C. E. F. Clark, T. B. McAllister, K. J. Hutchinson, and J. M. Lee. 2012. Chicory and plantain as feeds for dairy cows in late lactation. Pages 426-428 in Australasian Dairy Sci. Symp. Melbourne, Australia. Dairy Australia, Department of Primary Industries, Melbourne, Australia.

Muir, S. K., G. N. Ward, and J. L. Jacobs. 2014. Milk production and composition of mid-lactation cows consuming perennial ryegrassand chicory-based diets. J. Dairy Sci. 97:1005-1015.

National Health and Medical Research Council. 2004. Australian Code of Practice for the Care and Use of Animals for Scientific Purposes. 7th ed. Australian Government, Canberra, Australia.

Shenk, J. S., and M. O. Westerhaus. 1991. Population definition, sample selection and calibration proceedures for near infrared reflectance spectroscopy. Crop Sci. 31:469-474.
Skinner, R. H., D. L. Gustine, and M. A. Sanderson. 2004. Growth, water relations and nutritive value of species mixes under moisture stress. Crop Sci. 44:1361-1369.

Soder, K. J., M. A. Sanderson, J. L. Stack, and L. D. Muller. 2006. Intake and performance of lactating dairy cows grazing diverse forage mixes. J. Dairy Sci. 89:2158-2167.

Standing Committee on Agriculture. 1990. Feeding Standards for Australian Livestock: Ruminants. CSIRO, Melbourne, Australia.

Sukhija, P. S., and D. L. Palmquist. 1988. Rapid method for determination of total fatty acid content and composition of feedstuffs and feces. J. Agric. Food Chem. 36:1202-1206.

Tharmaraj, J., D. F. Chapman, Z. N. Nie, and A. P. Lane. 2008 Herbage accumulation, botanical composition, and nutritive value of five pasture types for dairy production in southern Australia. Aust. J. Agric. Res. 59:127-138.

Tyrrell, H. F., and J. T. Reid. 1965. Prediction of the energy value of cow's milk. J. Dairy Sci. 48:1215-1223.

Van Soest, P. J., and R. H. Wine. 1967. Use of detergents in the analysis of fibrous feeds. IV. Determination of plant cell wall constituents. J. Assoc. Off. Anal. Chem. 50:50-55.

Wales, W. J., J. W. Heard, C. K. M. Ho, C. M. Leddin, C. R. Stockdale, G. P. Walker, and P. T. Doyle. 2006. Profitable feeding of dairy cows on irrigated dairy farms in northern Victoria. Aust. J. Exp. Agric. 46:743-752.

Waugh, C. D., D. A. Clark, S. L. Harris, E. R. Thom, P. J. A. Copeman, and A. R. Napper. 1998. Chicory for milk production. Pages 33-37 in Proc. N. Z. Grassl. Assoc., vol. 60. New Zealand Grassland Association, Dunedin, New Zealand. 